\title{
Estrogenic botanical supplements, health-related quality of life, fatigue, and hormone-related symptoms in breast cancer survivors: a HEAL study report
}

Huiyan Ma ${ }^{1 *}$, Jane Sullivan-Halley ${ }^{1}$, Ashley W Smith², Marian L Neuhouser ${ }^{3}$, Catherine M Alfano ${ }^{2}$, Kathleen Meeske ${ }^{4}$, Stephanie M George ${ }^{5}$, Anne McTiernan ${ }^{3}$, Roberta McKean-Cowdin ${ }^{6}$, Kathy B Baumgartner ${ }^{7}$, Rachel Ballard-Barbash ${ }^{2}$ and Leslie Bernstein ${ }^{1}$

\begin{abstract}
Background: It remains unclear whether estrogenic botanical supplement (EBS) use influences breast cancer survivors' health-related outcomes.

Methods: We examined the associations of EBS use with health-related quality of life (HRQOL), with fatigue, and with 15 hormone-related symptoms such as hot flashes and night sweats among 767 breast cancer survivors participating in the Health, Eating, Activity, and Lifestyle (HEAL) Study. HRQOL was measured by the Medical Outcomes Study short form-36 physical and mental component scale summary score. Fatigue was measured by the Revised-Piper Fatigue Scale score.

Results: Neither overall EBS use nor the number of EBS types used was associated with HRQOL, fatigue, or hormone-related symptoms. However, comparisons of those using each specific type of EBS with non-EBS users revealed the following associations. Soy supplements users were more likely to have a better physical health summary score (odds ratio $[\mathrm{OR}]=1.66,95 \%$ confidence interval $[\mathrm{Cl}]=1.02-2.70$ ). Flaxseed oil users were more likely to have a better mental health summary score $(\mathrm{OR}=1.76,95 \% \mathrm{Cl}=1.05-2.94)$. Ginseng users were more likely to report severe fatigue and several hormone-related symptoms (all ORs $\geq 1.7$ and all 95\% Cls exclude 1). Red clover users were less likely to report weight gain, night sweats, and difficulty concentrating (all OR approximately 0.4 and all $95 \% \mathrm{Cls}$ exclude 1). Alfalfa users were less likely to experience sleep interruption ( $\mathrm{OR}=0.28,95 \% \mathrm{Cl}=0.12-0.68)$. Dehydroepiandrosterone users were less likely to have hot flashes $(\mathrm{OR}=0.33,95 \% \mathrm{Cl}=0.14-0.82)$.
\end{abstract}

Conclusions: Our findings indicate that several specific types of EBS might have important influences on a woman's various aspects of quality of life, but further verification is necessary.

\section{Background}

Breast cancer survivors frequently use complementary/ alternative medicines (CAM) such as estrogenic botanical supplements (EBS) in hopes of improving their health-related quality of life (HRQOL), boosting their sense of well-being, and alleviating the side-effects of conventional therapies $[1,2]$. However, no published

\footnotetext{
* Correspondence: hma@coh.org

'Division of Cancer Etiology, Department of Population Sciences, Beckman Research Institute, City of Hope, Duarte, CA 91010, USA

Full list of author information is available at the end of the article
}

data exist regarding the associations of EBS use with HRQOL, fatigue, or symptoms often characterized by a deficit of estrogen.

Botanical supplements are plant parts such as bark, leaves, stems, roots, flowers, fruits, seeds and berries or their extracts that are sold as pills, capsules or extracts [3]. EBS refer specifically to botanical supplements with phytoestrogenic components that may have weak estrogenic properties, directly alter estrogen levels, or function directly on receptors in different organs as either pro- or anti-estrogens [4]. EBS effects may differ

\section{() Biomed Central}

(c) 2011 Ma et al; licensee BioMed Central Ltd. This is an Open Access article distributed under the terms of the Creative Commons Attribution License (http://creativecommons.org/licenses/by/2.0), which permits unrestricted use, distribution, and reproduction in any medium, provided the original work is properly cited. 
depending upon concentration or the different components within different plant source [5].

High estrogen levels are well-documented risk factors for breast cancer [6-8] and anti-estrogenic therapy is a mainstay of adjuvant treatment for breast cancer [9]. Studies of the EBS impact on endogenous estrogen levels are mixed, showing increased [10], reduced [4], or no association with circulating levels of estrogen $[11,12]$. We previously showed that, among postmenopausal breast cancer survivors participating in the Health, Eating, Activity, and Lifestyle (HEAL) Study, EBS users had lower estrone, estradiol and free estradiol levels than non-EBS users [13].

Previous epidemiologic studies among breast cancer survivors have examined the associations of CAM or botanical supplements with HRQOL and hormonerelated symptoms showing that use was associated with poorer mental health function [14-17], poorer physical health function $[17,18]$, and hormone-related symptoms listed by the National Surgical Adjuvant Breast and Bowel Project Breast Cancer Prevention Trial $[14,19]$. However, none of these studies specifically focused on EBS use.

Here, we examine a new hypothesis to determine whether EBS use (overall, by number of EBS types, or by specific type used) is associated with HRQOL, fatigue, or 15 hormone-related symptoms among breast cancer survivors who had survived an average of 30 months after their first primary in situ or invasive breast cancer diagnosis.

\section{Methods \\ Study population}

Women participating in the HEAL Study, a multicenter, multiethnic, prospective study of 1, 183 women diagnosed with first primary in situ or invasive breast cancer between 1994 and 1999, provided the data for this analysis $[20,21]$. Breast cancer survivors were recruited within 12 months (mean $=6.1$ months) following their breast cancer diagnosis through the Surveillance Epidemiology and End Results (SEER) registries in New Mexico $(n=615)$, Western Washington $(n=202)$, and Los Angeles County $(\mathrm{n}=366)$.

Of 1,183 women who completed the baseline survey, $944(80 \%)$ participated in a second assessment approximately 30 months (mean $=30.4$ months) after diagnosis. Of the non-participants, 44 were deceased, 104 refused to participate, 55 could not be located, 17 could not be contacted, and 19 were too ill.

Of the original 1, 183 women, 858 (73\%) completed a third assessment approximately 40 months (mean $=40.6$ months) after diagnosis. Of the non-participants, 75 were deceased, 140 refused to participate, 49 could not be located, 50 could not be contacted, and 11 were too ill.
Among 829 women who completed all three surveys, we excluded 41 women who had subsequent recurrences or new primaries before their 30-month assessment, because these subsequent events and corresponding treatments might influence both EBS use and multiple health-related outcomes of interest. This yielded a preliminary analytic sample of 788 women.

All participants provided informed consent before each survey. The Institutional Review Boards at participating centers approved study protocols, in accordance with assurances filed with and approved by the United States Department of Health and Human Services.

\section{Data collection}

Diagnosis date and stage of breast cancer were based on SEER data. Treatment data (surgery, radiation therapy, and chemotherapy) were abstracted from medical records or, when unavailable, from SEER data.

Baseline in-person interviews in New Mexico and Los Angeles and self-administered questionnaires in Washington provided data on education, race/ethnicity, birth date, and height (measured in clinics in Washington and New Mexico and self-reported in Los Angeles).

Participants were asked about EBS use in the 30month assessment: "Since your cancer diagnosis have you taken any herbal or alternative remedies?" Participants who answered yes were given a list of $34 \mathrm{com}$ monly used botanical or herbal supplements and asked to indicate which, if any, of these supplements they used. An "Other" category was used to collect supplements that were not on the list; 94 distinct supplements were recorded via this open-ended question.

We reviewed all botanical-type supplements for evidence of estrogenicity using the Physician's Desk Reference for Herbal Medicines (PDR-H) [22]. For some supplements, evidence of estrogenicity was not clearly defined; however, we considered a supplement as estrogenic if at least one study (in vitro, animal or human) was cited that showed estrogenic properties. For supplements not found in the PDR-H, we consulted HerbDrug Interactions in Oncology (HDIO) [23] or the Natural Medicines Comprehensive Database (NMCD) [24]. A majority of supplements (90/128, 70\%) were identified in the PDR-H, six supplements (5\%) in HDIO and the remaining 32 supplements $(25 \%)$ in the NMCD. Of the 128 botanical/herbal supplements used by HEAL participants, 19 had estrogenic properties based on our definition, which included soy supplements, ginseng, flaxseed oil, black cohosh [Cimicifuga racemosa], yam, dong quai, red clover, licorice, alfalfa, cat's claw, dehydroepiandrosterone (DHEA), astragalus, boron, burdock root, fo ti tieng, nettles, saw palmetto, turmeric, and a combination supplement (containing soy, black cohosh, licorice, and dong quai). 
Information was collected during the 30-month survey on menopausal status, hormone therapy (HT) use, physical activity, tamoxifen use, and weight. Menopausal status was determined by age, menstrual status in the past year, HT use, number of ovaries and history of hysterectomy using an algorithm that assigned women into premenopausal, postmenopausal or unclassifiable menopausal status. Physical activity was measured using a version of the Modifiable Activity Questionnaire [25] adapted for this study; the type, duration, and frequency of 20 activities (e.g., walking, jogging, aerobics, tennis) during the past year were assessed. The MET intensity of each activity was classified as light, moderate, or vigorous based on its rating in the Compendium of Physical Activities [26]. MET hours per week of sports activity and recreational physical activity were combined into a total score and categorized (0, 0.1-8.9, $\geq 9$ MET hours/week) based on prior analyses in this cohort [27]. Weight was measured in clinics in Western Washington and New Mexico and during interviews in Los Angeles. Body mass index $\left(\mathrm{kg} / \mathrm{m}^{2}\right)$ was based on weight measured at the 30-month survey and height collected at the baseline survey.

In the 30-month survey, we inquired whether participants had been diagnosed by a physician with any of 18 chronic medical conditions (e.g., angina, arthritis, osteoporosis, chronic lung disease, diabetes, other cancers) and, if yes, whether that condition limited current activities of daily living. Medical comorbidity was calculated as the number of conditions reported as limiting current activities of daily living. We measured diet using a 122item self-administered food-frequency questionnaire (FFQ) developed and validated for the Women's Health Initiative [28]. Isoflavones (mg/day) from soy-containing foods on the FFQ were estimated as the sum of dietary genestein and dietary daidzein.

We assessed participants' HRQOL using the Medical Outcomes Study short form-36 (SF-36) questionnaire during the 40-month survey [29]. This tool contains 36 items and provides a physical component summary (PCS) scale and a mental component summary (MCS) scale. The two SF-36 summary scales are both valid and reliable [29-31]. These scales were scored in reference to a normal population (the 1998 general US population, standard form) with a transformed mean of 50, and a standard deviation of 10 [32]. Higher scores on each scale represent better QOL; summary scale scores above 50 indicate that QOL is above average.

We also used the Revised-Piper Fatigue Scale to assess fatigue at the 40-month assessment [33]. This scale contains 22 items, measures four dimensions of subjective fatigue (behavioral, sensory, cognitive/mood and affective), and provides an overall total fatigue score, with higher scores indicating a greater degree of fatigue. We used an adapted version of the Revised-Piper Fatigue Scale score [34] that asks survivors to rate their fatigue over the past month rather than the past week to minimize the effect of acute situational events and to enhance our assessment of the survivor's general state of fatigue. The Revised-Piper Fatigue Scale score has demonstrated acceptable internal consistency, content validity and concurrent criterion validity with adult cancer survivors [35-37].

We used a modified 15-symptom version of the National Surgical Adjuvant Breast and Bowel Project Breast Cancer Prevention Trial checklist $[19,38]$ to collect information on hormone-related symptoms at the 40-month survey asking women to indicate how much they were bothered by any of the problems during the past year only. The symptoms surveyed were hot flashes, difficulty with bladder control when laughing or crying, difficulty with bladder control at other times such as when coughing or sneezing, vaginal discharge, genital itching/irritation, pain with intercourse, breast sensitivity/tenderness, weight gain, unhappy with bodily appearance, forgetfulness, tendency to take naps/stay in bed, night sweats, difficulty concentrating, easily distracted, interrupted sleep, irritability and mood swings. Response options for the amount bothered by the symptoms were: "Not at all", "Slightly", "Moderately", "Quite a bit", "Extremely". Women who responded "Not at all" for a given symptom were considered not to have experienced that symptom.

\section{Statistical analysis}

We compared EBS users with non-users using Pearson $\chi^{2}$ tests to evaluate differences in the frequency distributions of categorical variables and $t$ tests to evaluate differences in means of continuous variables.

We treated the PCS scores, MCS scores, and total fatigue scores as continuous variables and also dichotomized the scores (low, high). Both PCS and MCS scores were dichotomized at the standardized mean of 50 (< $50, \geq 50$ ) [32], which has been used previously $[39,40]$. The cut point for total fatigue scores was based on prior work in this cohort $(<4, \geq 4)$ [41].

Multivariable linear regression models were fit to examine whether overall EBS use (no, yes), number of EBS types (none, 1 type, $\geq 2$ types), or specific type of EBS (soy supplements, ginseng, flaxseed oil, black cohosh, yam, dong quai, red clover, licorice, alfalfa, cat's claw, DHEA, or other EBS) was associated with continuous values of the PCS scores, MCS scores, and total fatigue scores. We fit multivariable unconditional logistic regression models using dichotomous outcome measures to determine whether EBS use was associated with high PCS $(\geq 50)$, MCS $(\geq 50)$, or total fatigue scores $(\geq$ 4 ). Odds ratios (ORs) and 95\% confidence intervals 
(CIs) for EBS use were estimated from these models. We also fit multivariable unconditional logistic regression models, to examine whether EBS use was associated with each hormone-related symptom (yes vs. no).

All multivariable regression models adjusted for variables that were statistically significantly different when comparing EBS users to non-users in Table 1: education, age at diagnosis, medicial comorbidity, MET hours per week of sports activity and recreational physical activity from 30-month interview, a combined variable for menopause and HT use, and isoflavones from soycontaining foods. In the analyses of individual types of EBS, we adjusted for all other types of EBS used.

To use a constant sample size, we excluded 21 women who were missing information on education $(n=1)$, medical comorbidity $(\mathrm{n}=1)$, MET hours per week of sports activity and recreational physical activity from 30month interview $(n=3)$, isoflavones from soy-containing foods $(n=12)$, HRQOL scores $(n=1)$, or fatigue scores $(n=3)$. The 21 women did not differ from the remaining 767 women on age at diagnosis, breast cancer stage, or treatment for breast cancer.

In reporting results from regression analyses, we considered a two-sided $P$ value $\leq 0.05$ as statistically significant. We did not adjust $P$ values for multiple comparisons as these analyses were considered as exploratory [42]. All analyses were performed using the SAS statistical package (Version 9.2, SAS Institute, Cary, NC).

\section{Results}

\section{Characteristics of EBS users and non-users}

EBS was used by $39.5 \%$ of women after their breast cancer diagnoses, including $18.4 \%$ who used only one type and $21.1 \%$ who used two or more EBS types. Soy supplements (16.6\%), ginseng (13.4\%), and flaxseed oil (13.0\%) were the most commonly used EBS types.

EBS users were more educated $\left(P_{\chi}{ }^{2}<0.0001\right)$, younger at diagnosis $\left(P_{\mathrm{t} \text {-test }}<0.0001\right)$, more physically active $\left(P_{\chi}{ }^{2}\right.$ $<0.0001)$, less likely to have medical comorbidity $\left(P_{\chi}{ }^{2}=\right.$ $0.007)$, more likely to be premenopausal $\left(P_{\chi}{ }^{2}=0.01\right)$, and more likely to consume isoflavones from soy-containing foods $\left(P_{\mathrm{t} \text {-test }}=0.002\right)$ than non-EBS users (Table 1$)$.

\section{EBS use and HRQOL}

Neither overall EBS use nor number of EBS types used was associated with continuous or dichotomous HRQOL scores (Table 2). However, a statistically nonsignificant positive association was observed between soy supplement use and continuous PCS scores $(P=$ 0.08 ). Soy supplement users had $66 \%$ greater odds (OR $=1.66,95 \% \mathrm{CI}=1.02-2.70)$ of a high $(\geq 50)$ PCS score; but no association was observed with MCS score. Ginseng use was negatively associated with the continuous PCS score $(P=0.008)$; ginseng users has $32 \%$ decreased odds of a high $(\geq 50)$ PCS score $(\mathrm{OR}=0.68,95 \% \mathrm{CI}=$ 0.40-1.15); no association was observed with MCS score. The use of flaxseed oil was not associated with continuous or dichotomous PCS score. However, the use of flaxseed oil was statistically non-significantly positively associated with the continuous MCS score $(P=0.06)$. Flaxseed oil users had $76 \%$ greater odds $(\mathrm{OR}=1.76$, $95 \% \mathrm{CI}=1.05-2.94)$ of a high $(\geq 50)$ MCS score than non-EBS users.

\section{EBS use and total fatigue score}

Neither overall EBS use nor number of EBS types used was associated with fatigue in the linear or logistic regression analyses (Table 3 ). Ginseng use was associated with greater fatigue measured continuously $(P=$ $0.002)$ as well as in the dichotomous form $(\mathrm{OR}=1.70$, 95\% CI $=1.04-2.76)$.

\section{EBS use and hormone-related symptoms}

Although we examined the potential associations for all the 15 symptoms with overall EBS use, number of EBS types, and each specific EBS, we observed no associations with overall EBS use, number of EBS types, or the majority of specific EBS. We limited presentation of results to four specific EBS types (ginseng, red clover, alfalfa, and DHEA) and the 10 symptoms where we observed at least one statistically significant association (Table 4). Ginseng use was positively associated with vaginal discharge, unhappiness with bodily appearance, forgetfulness, tendency to take naps or stay in bed, and irritability and mood swings (all ORs > 1.8 and all 95\% CIs exclude 1). Red clover users were less likely to report weight gain, night sweats, and difficulty concentrating (all OR approximately 0.4 and all 95\% CIs exclude 1). Alfalfa users were less likely than non-supplement users to have interrupted sleep $(\mathrm{OR}=0.28$, $95 \% \mathrm{CI}=0.12-0.68)$. DHEA users were less likely than non-supplement users to have hot flashes $(\mathrm{OR}=0.33$, 95\% CI $=0.14-0.82$ ).

\section{Discussion}

In the HEAL Study, neither overall EBS use nor the number of EBS types used was associated with HRQOL, fatigue, or hormone-related symptoms. Use of specific EBS types (soy supplements, ginseng, flaxseed oil, red clover, alfalfa, and DHEA) was associated with several outcomes of interest and we focus the discussion on these forms of EBS.

It is postulated that associations between soy supplements and breast cancer risk or progression may be in part related to the presence of isoflavones, which bind to estrogen receptors and activate estrogen response genes, although the hormone-like effect is much weaker than that of endogenous estradiol or estrone [43]. The 
Table 1 Study population characteristics by estrogenic botanical supplement (EBS) use

\begin{tabular}{|c|c|c|c|}
\hline & $\begin{array}{l}\text { No. non-EBS users (\%) } \\
N=464\end{array}$ & $\begin{array}{l}\text { No. EBS users (\%) } \\
N=303\end{array}$ & $P$ value $^{a}$ \\
\hline Study site & & & 0.12 \\
\hline Western Washington & $90(19.4)$ & $70(23.1)$ & \\
\hline New Mexico & $259(55.8)$ & $146(48.2)$ & \\
\hline Los Angeles County & $115(24.8)$ & $87(28.7)$ & \\
\hline Race & & & 0.63 \\
\hline Non-Hispanic white & $281(60.6)$ & $173(57.1)$ & \\
\hline African-American & $115(24.8)$ & $88(29.0)$ & \\
\hline Hispanic & $53(11.4)$ & $33(10.9)$ & \\
\hline Others & $15(3.2)$ & $9(3.0)$ & \\
\hline Education & & & $<0.0001$ \\
\hline$\leq$ High school & $143(30.8)$ & $51(16.8)$ & \\
\hline Technical school or some college & $154(33.2)$ & $126(41.6)$ & \\
\hline College graduate & $167(36.0)$ & $126(41.6)$ & \\
\hline Mean age at diagnosis $\left(S D^{b}\right)$, years & $56.0(10.6)$ & $52.5(8.7)$ & $<0.0001^{\mathrm{c}}$ \\
\hline Stage at diagnosis & & & 0.41 \\
\hline In situ & $110(23.7)$ & $60(19.8)$ & \\
\hline Localized & $257(55.4)$ & $173(57.1)$ & \\
\hline Regional & $97(20.9)$ & $70(23.1)$ & \\
\hline Breast cancer treatment & & & 0.43 \\
\hline No radiation and no chemotherapy & $155(33.4)$ & $86(28.4)$ & \\
\hline Radiation only & $171(36.9)$ & $116(38.3)$ & \\
\hline Chemotherapy only & $45(9.7)$ & $29(9.6)$ & \\
\hline Radiation and chemotherapy & $93(20.0)$ & $72(23.8)$ & \\
\hline Tamoxifen use & & & 0.24 \\
\hline No & $248(53.5)$ & $175(57.8)$ & \\
\hline Yes & $216(46.6)$ & $128(42.2)$ & \\
\hline Medical comorbidity & & & 0.007 \\
\hline None & $332(71.6)$ & $243(80.2)$ & \\
\hline 1 or more condition(s) & $132(28.5)$ & $60(19.8)$ & \\
\hline $\begin{array}{l}\text { Activity level within the past year of } 30 \text {-month interview from sports/recreation } \\
\text { (MET hours/week) }\end{array}$ & & & $<0.0001$ \\
\hline 0 & $93(20.0)$ & $33(10.9)$ & \\
\hline $0.1-8.9$ & $201(43.3)$ & $115(38.0)$ & \\
\hline$\geq 9$ & $170(36.6)$ & $155(51.2)$ & \\
\hline Menopausal status at 30-month interview & & & 0.01 \\
\hline Premenopausal & $74(16.0)$ & $68(22.4)$ & \\
\hline \multicolumn{4}{|l|}{ Postmenopausal } \\
\hline Never $\mathrm{HT}^{\mathrm{d}}$ after diagnosis & $193(41.6)$ & $135(44.6)$ & \\
\hline Ever $\mathrm{HT}^{\mathrm{d}}$ after diagnosis & $172(37.1)$ & $80(26.4)$ & \\
\hline Unknown & $25(5.4)$ & $20(6.6)$ & \\
\hline Body mass index at 30-month interview $\left(\mathrm{kg} / \mathrm{m}^{2}\right)$ & & & 0.13 \\
\hline$<25$ & $180(38.8)$ & $128(42.2)$ & \\
\hline $25-29$ & $133(28.7)$ & $97(32.0)$ & \\
\hline$\geq 30$ & $151(32.5)$ & $78(25.7)$ & \\
\hline Mean isoflavones from soy-containing foods $\left(\mathrm{SD}^{\mathrm{b}}\right), \mathrm{mg} /$ day & $1.9(9.4)$ & $4.0(9.9)$ & $0.002^{c}$ \\
\hline
\end{tabular}

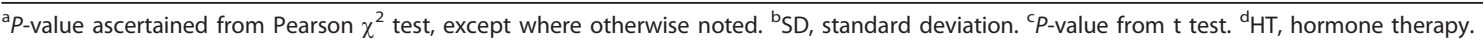

estrogen-antagonist/-agonist effects of isoflavones may depend on a woman's endogenous estrogen levels or on the isoflavones concentration in the EBS compound. These compounds may function as estrogen agonists in women with low estrogen levels [44]. Results from clinical trials which have evaluated the impact of soy products on hot flashes are mixed; three showed no effect in breast cancer survivors [45-47] and one showed 
Table 2 The association between estrogenic botanical supplement (EBS) use and health-related quality of life (HRQOL) score

\begin{tabular}{|c|c|c|c|c|c|c|}
\hline & \multicolumn{3}{|c|}{ Association with continuous HRQOL score } & \multicolumn{3}{|c|}{ Association with better HRQOL $(\geq 50)$} \\
\hline & No. & $\begin{array}{l}\text { Adjusted regression coefficient } \\
\text { (standard error) }\end{array}$ & $\begin{array}{l}P \\
\text { value }\end{array}$ & $\begin{array}{l}\text { No. with low score } \\
<50\end{array}$ & $\begin{array}{l}\text { No. with high score } \\
\geq 50\end{array}$ & $\begin{array}{l}\text { Adjusted OR } \\
(95 \% \mathrm{Cl})\end{array}$ \\
\hline \multicolumn{7}{|c|}{ Association with physical component summary (PCS) } \\
\hline \multicolumn{7}{|l|}{$\begin{array}{l}\text { Ever used EBS after } \\
\text { diagnosis }^{\mathrm{a}}\end{array}$} \\
\hline No & 464 & & & 228 & 236 & 1.00 \\
\hline Yes & 303 & $-1.27(0.67)$ & 0.06 & 142 & 161 & $0.84(0.60-1.18)$ \\
\hline \multicolumn{7}{|c|}{ By number of EBS used ${ }^{a}$} \\
\hline 1 & 141 & $-1.56(0.86)$ & 0.07 & 66 & 75 & $0.83(0.54-1.28)$ \\
\hline$\geq 2$ & 162 & $-0.99(0.84)$ & 0.24 & 76 & 86 & $0.85(0.56-1.28)$ \\
\hline \multicolumn{7}{|l|}{ By type of EBS used ${ }^{a, b}$} \\
\hline Soy supplements & 127 & $1.63(0.93)$ & 0.08 & 52 & 75 & $1.66(1.02-2.70)$ \\
\hline Ginseng & 103 & $-2.77(1.04)$ & 0.008 & 55 & 48 & $0.68(0.40-1.15)$ \\
\hline Flaxseed oil & 100 & $0.41(1.07)$ & 0.70 & 41 & 59 & $1.20(0.68-2.09)$ \\
\hline Black cohosh & 68 & $-0.70(1.31)$ & 0.59 & 35 & 33 & $0.66(0.35-1.27)$ \\
\hline Yam & 47 & $1.13(1.51)$ & 0.45 & 19 & 28 & $1.52(0.70-3.27)$ \\
\hline Dong quai & 39 & $-1.17(1.65)$ & 0.48 & 21 & 18 & $0.70(0.31-1.61)$ \\
\hline Red clover & 38 & $-1.40(1.70)$ & 0.41 & 22 & 16 & $0.61(0.26-1.41)$ \\
\hline Licorice & 37 & $1.37(1.62)$ & 0.40 & 17 & 20 & $1.50(0.64-3.47)$ \\
\hline Alfalfa & 31 & $-0.86(1.76)$ & 0.62 & 19 & 12 & $0.65(0.26-1.60)$ \\
\hline Cat's claw & 24 & $-2.38(2.00)$ & 0.23 & 13 & 11 & $0.80(0.28-2.28)$ \\
\hline DHEA & 24 & $-1.65(1.85)$ & 0.37 & 16 & 8 & $0.40(0.15-1.07)$ \\
\hline Other EBS & 34 & $1.26(1.67)$ & 0.45 & 16 & 18 & $1.17(0.50-2.76)$ \\
\hline
\end{tabular}

Ever used EBS after

Association with mental component summary (MCS)

\section{diagnosis $^{\mathrm{a}}$}

$\begin{array}{lll}\text { No } & 464 & \\ \text { Yes } & 303 & 0.57(0.80)\end{array}$

200
$0.48 \quad 122$

$0.43 \quad 58$

$0.73 \quad 64$
1.00

$1.16(0.85-1.57)$

By number of EBS used ${ }^{a}$

$\begin{array}{lll}1 & 141 & 0.80(1.02) \\ \geq 2 & 162 & 0.35\end{array}$

By type of EBS used ${ }^{a, b}$

$\begin{array}{lll}\text { Soy supplements } & 127 & 1.06(1.11) \\ \text { Ginseng } & 103 & -0.80(1.24) \\ \text { Flaxseed oil } & 100 & 2.39(1.28) \\ \text { Black cohosh } & 68 & -0.50(1.57) \\ \text { Yam } & 47 & -0.36(1.81) \\ \text { Dong quai } & 39 & 1.28(1.97) \\ \text { Red clover } & 38 & 0.75(2.04) \\ \text { Licorice } & 37 & -1.09(1.95) \\ \text { Alfalfa } & 31 & -0.11(2.10) \\ \text { Cat's claw } & 24 & -3.07(2.40) \\ \text { DHEA } & 24 & 1.49(2.22) \\ \text { Other EBS } & 34 & 0.19(2.00)\end{array}$

$\begin{array}{ll}0.34 & 44 \\ 0.52 & 44 \\ 0.06 & 33 \\ 0.75 & 28 \\ 0.84 & 18 \\ 0.52 & 16 \\ 0.71 & 14 \\ 0.57 & 16 \\ 0.96 & 13 \\ 0.20 & 12 \\ 0.50 & 10 \\ 0.93 & 12\end{array}$

$1.42(0.92-2.20)$

$0.88(0.55-1.42)$

$1.76(1.05-2.94)$

$0.94(0.52-1.73)$

$1.14(0.56-2.31)$

$0.98(0.46-2.11)$

$1.15(0.51-2.57)$

$0.79(0.37-1.67)$

$0.89(0.40-2.00)$

$0.52(0.21-1.30)$

$0.93(0.40-2.21)$

$1.25(0.57-2.75)$

${ }^{a}$ Adjusted for education, age at diagnosis, medical comorbidity, activity level within the past year of 30-month interview, a combined variable for menopause and hormone therapy, isoflavones from soy-containing foods. ${ }^{b}$ Additionally, all types mutually adjusted. 
Table 3 The association between estrogenic botanical supplement (EBS) use and total fatigue score

\begin{tabular}{|c|c|c|c|c|c|c|}
\hline & \multicolumn{3}{|c|}{ Association with continuous total fatigue score } & \multicolumn{3}{|c|}{ Association with severe fatigue $(\geq 4)$} \\
\hline & No. & $\begin{array}{l}\text { Adjusted regression coefficient (standard } \\
\text { error) }\end{array}$ & $\begin{array}{l}P \\
\text { value }\end{array}$ & $\begin{array}{l}\text { No. with PFS }< \\
4\end{array}$ & $\begin{array}{l}\text { No. with PFS } \geq \\
4\end{array}$ & $\begin{array}{l}\text { Adjusted OR }(95 \% \\
\text { CI) }\end{array}$ \\
\hline \multicolumn{7}{|l|}{$\begin{array}{l}\text { Ever used EBS after } \\
\text { diagnosis }^{\mathrm{a}}\end{array}$} \\
\hline No & 464 & & & 280 & 184 & 1.00 \\
\hline Yes & 303 & $0.13(0.17)$ & 0.44 & 179 & 124 & $1.06(0.78-1.45)$ \\
\hline \multicolumn{7}{|c|}{ By number of EBS used ${ }^{a}$} \\
\hline 1 & 141 & $0.11(0.21)$ & 0.59 & 86 & 55 & $0.98(0.66-1.46)$ \\
\hline$\geq 2$ & 162 & $0.14(0.21)$ & 0.50 & 93 & 69 & $1.14(0.78-1.69)$ \\
\hline \multicolumn{7}{|c|}{ By type of EBS used ${ }^{a, b}$} \\
\hline Soy supplements & 127 & $0.07(0.23)$ & 0.75 & 75 & 52 & $1.16(0.74-1.80)$ \\
\hline Ginseng & 103 & $0.81(0.26)$ & 0.002 & 54 & 49 & $1.70(1.04-2.76)$ \\
\hline Flaxseed oil & 100 & $-0.22(0.26)$ & 0.40 & 66 & 34 & $0.66(0.39-1.12)$ \\
\hline Black cohosh & 68 & $-0.17(0.32)$ & 0.60 & 43 & 25 & $0.78(0.41-1.46)$ \\
\hline Yam & 47 & $-0.003(0.37)$ & 0.99 & 30 & 17 & $0.94(0.45-1.96)$ \\
\hline Dong quai & 39 & $-0.25(0.40)$ & 0.53 & 24 & 15 & $0.83(0.38-1.81)$ \\
\hline Red clover & 38 & $-0.60(0.42)$ & 0.15 & 26 & 12 & $0.52(0.22-1.21)$ \\
\hline Licorice & 37 & $0.07(0.40)$ & 0.85 & 21 & 16 & $1.41(0.65-3.06)$ \\
\hline Alfalfa & 31 & $-0.39(0.43)$ & 0.36 & 21 & 10 & $0.72(0.30-1.71)$ \\
\hline Cat's claw & 24 & $0.79(0.49)$ & 0.11 & 12 & 12 & $2.03(0.76-5.42)$ \\
\hline DHEA & 24 & $0.27(0.45)$ & 0.55 & 11 & 13 & $1.96(0.82-4.70)$ \\
\hline Other EBS & 34 & $-0.57(0.41)$ & 0.16 & 22 & 12 & $0.79(0.35-1.77)$ \\
\hline
\end{tabular}

${ }^{a}$ Adjusted for education, age at diagnosis, medical comorbidity, activity level within the past year of 30-month interview, a combined variable for menopause and hormone therapy, isoflavones from soy-containing foods. ${ }^{b}$ Additionally, all types mutually adjusted.

protective effects in postmenopausal women experiencing $\geq 5$ hot flushes per day [48]. One randomized controlled trial observed that the incidence and severity of hot flashes were reduced two weeks after treatment with oral soy isoflavone extract, with no immediate reductions observed in the placebo group; the group differences achieved statistical significance at 6 weeks $(P=$ $0.03)$, but decreased by 12 weeks $(P=0.08)$ [48]. Soy supplement use in the HEAL Study participants was associated with a better PCS score, but not with other outcomes examined. Our results suggest, on the whole, that soy supplements are unlikely to be detrimental to breast cancer survivors' HRQOL, fatigue, or hormonerelated symptoms.

Ginsenosides (Rh1, Rb1, and Rg1) from ginseng have estrogen-like characteristics $[49,50]$ and hence ginseng might ease menopausal symptoms. Ginseng did not influence hot flashes in a randomized, double blind, placebo-controlled study of ginseng in women reporting high frequency of hot flashes [51]. An observational study conducted in 2-5 years Chinese breast cancer survivors reported that ginseng use after cancer diagnosis, particularly current use, was positively associated with higher HRQOL scores in the psychological and social well-being domains, but was not associated with scores in the physical domain [52]. The findings from China may not translate to US populations because the major type of ginseng used could be different. An epidemiologic study conducted in US breast cancer survivors who were, on average, 6.5 years post diagnosis reported that ginseng users had lower SF-36 MCS scores [16]. We observed that ginseng use was associated with a lower PCS score, a higher fatigue score, and several hormonerelated symptoms. Although these associations with different symptoms are consistent with previous studies outlining the adverse effects of ginseng [53-55], we cannot exclude the possibility that the symptoms experienced by women who took ginseng motivated their ginseng use.

Flaxseed oil is derived from the seeds of the flax plant that contain phytoestrogens and alpha-linolenic acid $[56,57]$. Colonic microflora convert phytoestrogens to enterolactone and enterodiol, both of which have estrogenic and antiestrogenic properties [58]. Alpha-linolenic acid had growth-inhibitory and proapoptotic effects on estrogen-positive breast cancer cells [59] and decreased the incidence, number, and growth of tumors in rats $[60,61]$. In human studies, flaxseed stabilized mood, 
Table 4 Adjusted $^{\mathrm{a}}$ OR $(95 \% \mathrm{Cl})$ for the association between estrogenic botanical supplement use and hormone-related symptoms during last years of 30-month survey

\begin{tabular}{|c|c|c|c|c|c|c|c|c|c|c|c|c|}
\hline & \multicolumn{3}{|r|}{ Ginseng } & \multicolumn{3}{|c|}{ Red Clover } & \multicolumn{3}{|r|}{ Alfalfa } & \multicolumn{3}{|r|}{ DHEA } \\
\hline & No & Yes & $\begin{array}{l}\text { Adjusted }^{\mathrm{a}} \text { OR } \\
(95 \% \mathrm{Cl})\end{array}$ & No & Yes & $\begin{array}{l}\text { Adjusted }^{\mathrm{a}} \text { OR } \\
\text { (95\% Cl) }\end{array}$ & No & Yes & $\begin{array}{l}\text { Adjusted }^{\mathrm{a}} \text { OR } \\
\text { (95\% CI) }\end{array}$ & No & Yes & $\begin{array}{l}\text { Adjusted }^{\mathrm{a}} \text { OR } \\
(95 \% \mathrm{Cl})\end{array}$ \\
\hline \multicolumn{13}{|c|}{ Hot flashes } \\
\hline No & 179 & 19 & 1.00 & 191 & 7 & 1.00 & 187 & 11 & 1.00 & 187 & 11 & 1.00 \\
\hline Yes & 485 & 84 & $1.41(0.76-2.63)$ & 538 & 31 & $0.99(0.34-2.85)$ & 549 & 20 & $0.43(0.17-1.08)$ & 556 & 13 & $0.33(0.14-0.82)$ \\
\hline \multicolumn{13}{|c|}{ Vaginal discharge } \\
\hline No & 427 & 53 & 1.00 & 457 & 23 & 1.00 & 460 & 20 & 1.00 & 466 & 14 & 1.00 \\
\hline Yes & 237 & 50 & $1.81(1.12-2.93)$ & 272 & 15 & $0.92(0.42-2.05)$ & 276 & 11 & $0.94(0.41-2.20)$ & 277 & 10 & $1.15(0.48-2.73)$ \\
\hline \multicolumn{13}{|c|}{ Weight gain } \\
\hline No & 234 & 37 & 1.00 & 253 & 18 & 1.00 & 257 & 14 & 1.00 & 262 & 9 & 1.00 \\
\hline Yes & 430 & 66 & $0.94(0.57-1.55)$ & 476 & 20 & $0.41(0.19-0.91)$ & 479 & 17 & $0.76(0.33-1.76)$ & 481 & 15 & $0.88(0.36-2.11)$ \\
\hline \multicolumn{13}{|c|}{$\begin{array}{l}\text { Unhappy with bodily } \\
\text { appearance }\end{array}$} \\
\hline No & 221 & 17 & 1.00 & 225 & 13 & 1.00 & 226 & 12 & 1.00 & 230 & 8 & 1.00 \\
\hline Yes & 443 & 86 & $2.58(1.38-4.81)$ & 504 & 25 & $0.49(0.21-1.17)$ & 510 & 19 & $0.67(0.28-1.60)$ & 513 & 16 & $0.76(0.30-1.93)$ \\
\hline \multicolumn{13}{|c|}{ Forgetfulness } \\
\hline No & 147 & 13 & 1.00 & 153 & 7 & 1.00 & 154 & 6 & 1.00 & 156 & 4 & 1.00 \\
\hline Yes & 517 & 90 & $2.19(1.11-4.33)$ & 576 & 31 & $1.09(0.40-2.98)$ & 582 & 25 & $1.09(0.39-3.02)$ & 587 & 20 & $1.38(0.43-4.42)$ \\
\hline \multicolumn{13}{|c|}{$\begin{array}{l}\text { Tendency to take naps, } \\
\text { stay in bed }\end{array}$} \\
\hline No & 326 & 39 & 1.00 & 346 & 19 & 1.00 & 352 & 13 & 1.00 & 357 & 8 & 1.00 \\
\hline Yes & 338 & 64 & $2.24(1.35-3.72)$ & 383 & 19 & $1.20(0.54-2.70)$ & 384 & 18 & $1.37(0.59-3.18)$ & 386 & 16 & $1.96(0.79-4.87)$ \\
\hline \multicolumn{13}{|c|}{ Night sweats } \\
\hline No & 272 & 31 & 1.00 & 285 & 18 & 1.00 & 288 & 15 & 1.00 & 293 & 10 & 1.00 \\
\hline Yes & 392 & 72 & $1.42(0.84-2.39)$ & 444 & 20 & $0.40(0.18-0.90)$ & 448 & 16 & $0.66(0.29-1.53)$ & 450 & 14 & $0.82(0.34-1.97)$ \\
\hline \multicolumn{13}{|c|}{ Difficulty concentrating } \\
\hline No & 268 & 34 & 1.00 & 282 & 20 & 1.00 & 292 & 10 & 1.00 & 293 & 9 & 1.00 \\
\hline Yes & 396 & 69 & $1.51(0.91-2.50)$ & 447 & 18 & $0.41(0.18-0.90)$ & 444 & 21 & $1.84(0.77-4.41)$ & 450 & 15 & $1.17(0.48-2.84)$ \\
\hline \multicolumn{13}{|c|}{ Interrupted sleeping } \\
\hline No & 146 & 18 & 1.00 & 154 & 10 & 1.00 & 151 & 13 & 1.00 & 157 & 7 & 1.00 \\
\hline Yes & 518 & 85 & $1.49(0.80-2.80)$ & 575 & 28 & $0.67(0.26-1.77)$ & 585 & 18 & $0.28(0.12-0.68)$ & 586 & 17 & $0.54(0.21-1.39)$ \\
\hline \multicolumn{13}{|c|}{$\begin{array}{l}\text { Irritability or mood } \\
\text { swings }^{b}\end{array}$} \\
\hline No & 270 & 24 & 1.00 & 283 & 11 & 1.00 & 281 & 13 & 1.00 & 282 & 12 & 1.00 \\
\hline Yes & 393 & 79 & $2.19(1.26-3.82)$ & 445 & 27 & $1.20(0.51-2.87)$ & 454 & 18 & $0.79(0.34-1.86)$ & 460 & 12 & $0.59(0.24-1.45)$ \\
\hline
\end{tabular}

${ }^{a}$ Adjusted for education, age at diagnosis, medical comorbidity, activity level within the past year of 30-month interview, a combined variable for menopause and hormone therapy, isoflavones from soy-containing foods. In addition, soy supplement, ginseng, flaxseed oil, black cohosh, yam, dong quai, red clover, licorice, alfalfa, DHEA, cat's claw, and other EBS use mutually adjusted. ${ }^{b}$ Excluded one woman with missing information of irritability or mood swings.

improved depression symptoms [62], and reduced blood pressure during mental stress induced by frustrating cognitive tasks [63]. Our results are consistent with these findings as flaxseed oil was associated with higher MCS scores.

Red clover is another source of isoflavones, and had some efficacy in reducing hot flashes, but did not influence quality of life, in a 12-week randomized clinical trial [64]. In the HEAL Study, red clover use was associated with neither HRQOL nor hot flashes. However, red clover users were less likely to report three symptoms (weight gain, night sweats, and difficulty concentrating) than non-EBS users. Although these results support an association of red clover with fewer menopausal symptoms, it is important to note that we had only 38 users.

Alfalfa also contains phytoestrogens and has weak estrogenic effects $[65,66]$. In animal studies, alfalfa was associated with antioxidant activity [67] and protected against atherosclerotic lesions [68]. A small Italian study of women experiencing hot flashes and night sweats found that use of alfalfa and sage extracts for three months completely alleviated symptoms in 20 of 30 women studied [69]. In the HEAL Study, alfalfa users had a substantial but non-statistically-significant lower risk for hot flashes and were less likely to report 
interrupted sleep than non-EBS users. These results based on 31 alfalfa users provide some evidence that alfalfa may reduce menopausal symptoms.

DHEA is an endogenous steroid produced and secreted by the adrenal gland. Its sulfated form is converted into androgens and estrogens by specific steroidogenic enzymes. Blood DHEA levels begin to decrease around age 30 , and by menopause are decreased $60 \%$, on average [70]. It is reasonable to speculate that DHEA supplements may alleviate the symptoms caused by estrogen deficiency. A study that administered $50 \mathrm{mg}$ of DHEA to 22 women found hot flash scores decreased $50 \%$ from baseline to week 5 of treatment [71]. In the HEAL Study, DHEA users had lower odds of hot flashes than non-EBS users. Our findings, based on 24 users, support that DHEA use may reduce hot flashes.

This study has several important limitations. First, the analysis relied on self-reported EBS use. Although our HRQOL and symptom data were collected, on average, 10 months after the information on EBS use that was collected, it is possible that the lower HRQOL or the symptoms experienced by women who took EBS were what motivated EBS use. This might bias our results towards the null value, underestimate the associations of EBS use with better health-related outcomes, or yield a false association of EBS use with poorer HRQOL or severe fatigue or other symptoms. Second, we were unable to rule out the possibility that some women might have changed their number or type of EBS they used, or non-EBS-users may have become users during an average of 10 month interval between our two surveys. If these events occurred, they would have biased our results toward the null, limiting our ability to detect associations with EBS use. Third, we did not collect some important information regarding EBS use such as when EBS use was initiated, duration or frequency of use, dosage level of supplements taken, or reasons for use. Furthermore, as this study is exploratory, we did not adjust for multiple comparisons. Clearly limitations restrict interpretation of observed associations. The results do provide preliminary information for future epidemiologic studies or clinical trials and add to the sparse literature on the association of EBS use with health-related outcomes.

We believe that this is the first epidemiologic analysis examining the potential association of overall EBS use, number of EBS types, and eleven commonly used types of EBS with multiple health-related outcomes. EBS use among breast cancer survivors is common, and data showing the efficacy of these agents (or lack thereof) on symptoms and HRQOL would be useful to survivors and their healthcare providers.

\section{Conclusions}

Our results indicate the importance of assessing specific types of EBS separately in future efficacy studies since they may have distinct associations with health-related outcomes. The roles of soy supplements, flaxseed oil, red clover, alfalfa, and DHEA, in the improvement of HRQOL or alleviation of fatigue or hormone-related symptoms among breast cancer survivors merit further exploration.

\section{List of abbreviations}

CAM: complementary/alternative medicines; Cl: confidence interval; DHEA: dehydroepiandrosterone; EBS: estrogenic botanical supplement; FFQ: foodfrequency questionnaire; HDIO: Herb-Drug Interactions in Oncology; HEAL: Health, Eating; Activity, and Lifestyle; HRQOL: health-related quality of life; HT: hormone therapy; MCS: mental component summary; NMCD: Natural Medicines Comprehensive Database; OR: odds ratio; SEER: Surveillance Epidemiology and End Results; PCS: physical component summary; PDR-H: Physician's Desk Reference for Herbal Medicines.

\section{Acknowledgements}

National Cancer Institute contracts N01-CN-5036-20, N01-CN-05228, N01-PC 67010/N01-PC-35139, N01-PC-67007/N01-PC-35138 and N01-PC-67009/N01PC-35142, and training grant T32 CA09661. A portion of this work was conducted through the Clinical Research Center at the University of Washington and supported by the NIH grant M01-RR-00037. Data collection for the Women's Contraceptive and Reproductive Experiences Study at the University of Southern California was supported by the National Institute of Child Health and Human Development contract N01-HD-3-3175. Patient identification was supported in part by the California Department of Health Services grant 050Q-8709-S1528.

\section{Author details}

'Division of Cancer Etiology, Department of Population Sciences, Beckman Research Institute, City of Hope, Duarte, CA 91010, USA. ${ }^{2}$ Division of Cancer Control and Population Sciences, National Cancer Institute, Bethesda, MD 20892, USA. ${ }^{3}$ Fred Hutchinson Cancer Research Center, Seattle, WA 98109, USA. ${ }^{4}$ Childrens Center for Cancer and Blood Diseases, Children's Hospital Los Angeles, Los Angeles, CA 90027, USA. ${ }^{5}$ Division of Cancer Epidemiology and Genetics, National Cancer Institute, Bethesda, MD 20892, USA.

${ }^{6}$ Department of Preventive Medicine, Keck School of Medicine, University of Southern California, Los Angeles, CA 90089, USA. ${ }^{7}$ Epidemiology and Clinical Investigation Sciences, School of Public Health \& Information Sciences, University of Louisville, Louisville, KY 40202, USA.

\section{Authors' contributions}

$A M, K B B, R B B$, and LB obtained funding for the HEAL Study, designed and implemented the HEAL surveys, and supervised data collection, data management, and data cleaning. HM conducted data analyses and drafted the manuscript. All authors participated in the revision of the manuscript and have read and approved the final version.

\section{Conflicts of interest statement}

The authors declare that they have no competing interests.

Received: 27 April 2011 Accepted: 8 November 2011 Published: 8 November 2011

\footnotetext{
References

1. Boon H, Stewart M, Kennard MA, Gray R, Sawka C, Brown JB, McWilliam C, Gavin A, Baron RA, Aaron D, Haines-Kamka T: Use of complementary/ alternative medicine by breast cancer survivors in Ontario: prevalence and perceptions. J Clin Oncol 2000, 18:2515-2521.

2. Nahleh Z, Tabbara IA: Complementary and alternative medicine in breast cancer patients. Palliat Support Care 2003, 1:267-273.

3. Food and drug administration: Food and drug administration. Dietary Supplement Health and Education Act of 1994., cited 2010 Aug 16.
} 
4. Kirk CJ, Harris RM, Wood DM, Waring RH, Hughes PJ: Do dietary phytoestrogens influence susceptibility to hormone-dependent cancer by disrupting the metabolism of endogenous oestrogens? Biochem Soc Trans 2001, 29:209-216.

5. Moutsatsou P: The spectrum of phytoestrogens in nature: our knowledge is expanding. Hormones (Athens) 2007, 6:173-193.

6. Henderson BE, Ross RK, Pike MC, Casagrande JT: Endogenous hormones as a major factor in human cancer. Cancer Res 1982, 42:3232-3239.

7. Bernstein L, Ross RK: Endogenous hormones and breast cancer risk. Epidemiol Rev 1993, 15:48-65.

8. Key TJ, Appleby PN, Reeves GK, Roddam A, Dorgan JF, Longcope C, Stanczyk FZ, Stephenson HE Jr, Falk RT, Miller R, et al: Body mass index, serum sex hormones, and breast cancer risk in postmenopausal women. J Natl Cancer Inst 2003, 95:1218-1226.

9. Burstein HJ, Prestrud AA, Seidenfeld J, Anderson H, Buchholz TA, Davidson NE, Gelmon KE, Giordano SH, Hudis CA, Malin J, et al: American society of clinical oncology clinical practice guideline: update on adjuvant endocrine therapy for women with hormone receptor-positive breast cancer. J Clin Oncol 2010, 28:3784-3796.

10. Wu WH, Liu LY, Chung CJ, Jou HJ, Wang TA: Estrogenic effect of yam ingestion in healthy postmenopausal women. J Am Coll Nutr 2005, 24:235-243.

11. Wu AH, Stanczyk FZ, Martinez C, Tseng CC, Hendrich S, Murphy P, Chaikittisilpa S, Stram DO, Pike MC: A controlled 2-mo dietary fat reduction and soy food supplementation study in postmenopausal women. Am J Clin Nutr 2005, 81:1133-1141.

12. Low YL, Taylor II, Grace PB, Dowsett M, Scollen S, Dunning AM, Mulligan AA, Welch AA, Luben RN, Khaw KT, et al: Phytoestrogen exposure correlation with plasma estradiol in postmenopausal women in European Prospective Investigation of Cancer and Nutrition-Norfolk may involve diet-gene interactions. Cancer Epidemiol Biomarkers Prev 2005, 14:213-220.

13. Wayne SJ, Neuhouser ML, Koprowski C, Ulrich CM, Wiggins C, Gilliland F, Baumgartner KB, Baumgartner RN, McTiernan A, Bernstein L, BallardBarbash R: Breast cancer survivors who use estrogenic botanical supplements have lower serum estrogen levels than non users. Breast Cancer Res Treat 2009, 117:111-119.

14. Burstein HJ, Gelber S, Guadagnoli E, Weeks JC: Use of alternative medicine by women with early-stage breast cancer. N Engl I Med 1999, 340:1733-1739.

15. Carpenter CL, Ganz PA, Bernstein L: Complementary and alternative therapies among very long-term breast cancer survivors. Breast Cancer Res Treat 2009, 116:387-396.

16. Ganz PA, Desmond KA, Leedham B, Rowland JH, Meyerowitz BE, Belin TR: Quality of life in long-term, disease-free survivors of breast cancer: a follow-up study. J Natl Cancer Inst 2002, 94:39-49.

17. Buettner $\mathrm{C}$, Kroenke $\mathrm{CH}$, Phillips RS, Davis RB, Eisenberg DM, Holmes MD: Correlates of use of different types of complementary and alternative medicine by breast cancer survivors in the nurses' health study. Breast Cancer Res Treat 2006, 100:219-227.

18. $\mathrm{Ma} \mathrm{H}$, Carpenter $\mathrm{CL}$, Sullivan-Halley J, Bernstein $\mathrm{L}$ : The roles of herbal remedies in survival and quality of life among long-term breast cancer survivors - results of a prospective study. BMC Cancer 2011, 11:222.

19. Ganz PA, Day R, Ware JE Jr, Redmond C, Fisher B: Base-line quality-of-life assessment in the National Surgical Adjuvant Breast and Bowel Project Breast Cancer Prevention Trial. J Natl Cancer Inst 1995, 87:1372-1382.

20. Irwin ML, MCTiernan A, Bernstein L, Gilliland FD, Baumgartner R, Baumgartner K, Ballard-Barbash R: Physical activity levels among breast cancer survivors. Med Sci Sports Exerc 2004, 36:1484-1491.

21. McTiernan A, Rajan KB, Tworoger SS, Irwin M, Bernstein L, Baumgartner R, Gilliland F, Stanczyk FZ, Yasui Y, Ballard-Barbash R: Adiposity and sex hormones in postmenopausal breast cancer survivors. $J$ Clin Oncol 2003, 21:1961-1966.

22. Gruendwald J, Brendler T, Jaenicke C: Physician's Desk Reference for Herbal Products. 4 edition. Montvale: Thompson Healthcare; 2007.

23. Cassileth BR, Lucarelli CD: Herb-drug interactions in oncology New York: BC Decker Inc:; 2003.

24. Jellin JM, Gregory PJ, et al: Natural medicine comprehensive database. 2007.

25. Kriska A: Modifiable Activity Questionnaire for Adolescents. Medicine Science in Sports Exercise 1997, 29:79-82.
26. Ainsworth BE, Haskell WL, Whitt MC, Irwin ML, Swartz AM, Strath SJ, O'Brien WL, Bassett DR Jr, Schmitz KH, Emplaincourt PO, et al: Compendium of physical activities: an update of activity codes and MET intensities. Med Sci Sports Exerc 2000, 32:S498-504.

27. Irwin ML, Smith AW, McTiernan A, Ballard-Barbash R, Cronin K, Gilliland FD, Baumgartner RN, Baumgartner KB, Bernstein L: Influence of pre- and postdiagnosis physical activity on mortality in breast cancer survivors: the health, eating, activity, and lifestyle study. J Clin Oncol 2008, 26:3958-3964.

28. Patterson RE, Kristal AR, Tinker LF, Carter RA, Bolton MP, Agurs-Collins T: Measurement characteristics of the Women's Health Initiative food frequency questionnaire. Ann Epidemiol 1999, 9:178-187.

29. Hays RD, Sherbourne CD, Mazel RM: The RAND 36-Item Health Survey 1.0. Health Econ 1993, 2:217-227.

30. Ware JE: SF-36 Physical and Mental Health Summary Scales: a user's manual. Second edition. Boston: The Health Institute; 1994.

31. Ware JE Jr, Kosinski M, Bayliss MS, McHorney CA, Rogers WH, Raczek A: Comparison of methods for the scoring and statistical analysis of SF-36 health profile and summary measures: summary of results from the Medical Outcomes Study. Med Care 1995, 33:AS264-279.

32. Ware JE: SF-36 physical \& mental health summary scales: a manual for users of version 1. Second edition. Lincoln, Rl: QualityMetric Incorporated; 2001

33. Piper BF, Dibble SL, Dodd MJ, Weiss MC, Slaughter RE, Paul SM: The revised Piper Fatigue Scale: psychometric evaluation in women with breast cancer. Oncol Nurs Forum 1998, 25:677-684.

34. Meeske KA, Siegel SE, Globe DR, Mack WJ, Bernstein L: Prevalence and correlates of fatigue in long-term survivors of childhood leukemia. J Clin Oncol 2005, 23:5501-5510.

35. Berger AM: Patterns of fatigue and activity and rest during adjuvant breast cancer chemotherapy. Oncol Nurs Forum 1998, 25:51-62.

36. Woo B, Dibble SL, Piper BF, Keating SB, Weiss MC: Differences in fatigue by treatment methods in women with breast cancer. Oncol Nurs Forum 1998, 25:915-920.

37. Wu HS, McSweeney M: Measurement of fatigue in people with cancer. Oncol Nurs Forum 2001, 28:1371-1384, quiz 1385-1376.

38. Alfano CM, McGregor BA, Kuniyuki A, Reeve BB, Bowen DJ, Baumgartner KB, Bernstein L, Ballard-Barbash R, Malone KE, Ganz PA, McTiernan A: Psychometric properties of a tool for measuring hormone-related symptoms in breast cancer survivors. Psychooncology 2006, 15:985-1000.

39. Lee C, Powers JR: Number of social roles, health, and well-being in three generations of Australian women. Int J Behav Med 2002, 9:195-215.

40. Islam S, Carter K, Mhurchu CN, Anderson CS: Selenium and zinc in hair and toenails in relation to the physical and mental health status of older adults: The Freemasons Health study in New Zealand. Australasian Journal on Ageing 2007, 26:180-186.

41. Meeske K, Smith AW, Alfano CM, McGregor BA, McTiernan A, Baumgartner KB, Malone KE, Reeve BB, Ballard-Barbash R, Bernstein L: Fatigue in breast cancer survivors two to five years post diagnosis: a HEAL Study report. Qual Life Res 2007, 16:947-960.

42. Bender R, Lange S: Adjusting for multiple testing-when and how? J Clin Epidemiol 2001, 54:343-349.

43. Kostelac D, Rechkemmer G, Briviba K: Phytoestrogens modulate binding response of estrogen receptors alpha and beta to the estrogen response element. J Agric Food Chem 2003, 51:7632-7635.

44. Hwang CS, Kwak HS, Lim HJ, Lee SH, Kang YS, Choe TB, Hur HG, Han KO: Isoflavone metabolites and their in vitro dual functions: they can act as an estrogenic agonist or antagonist depending on the estrogen concentration. J Steroid Biochem Mol Biol 2006, 101:246-253.

45. Quella SK, Loprinzi CL, Barton DL, Knost JA, Sloan JA, LaVasseur BI, Swan D, Krupp KR, Miller KD, Novotny PJ: Evaluation of soy phytoestrogens for the treatment of hot flashes in breast cancer survivors: A North Central Cancer Treatment Group Trial. J Clin Oncol 2000, 18:1068-1074.

46. MacGregor CA, Canney PA, Patterson G, McDonald R, Paul J: A randomised double-blind controlled trial of oral soy supplements versus placebo for treatment of menopausal symptoms in patients with early breast cancer. Eur J Cancer 2005, 41:708-714.

47. Van Patten CL, Olivotto IA, Chambers GK, Gelmon KA, Hislop TG, Templeton E, Wattie A, Prior JC: Effect of soy phytoestrogens on hot flashes in postmenopausal women with breast cancer: a randomized controlled clinical trial. J Clin Oncol 2002, 20:1449-1455. 
48. Upmalis DH, Lobo R, Bradley L, Warren M, Cone FL, Lamia CA: Vasomotor symptom relief by soy isoflavone extract tablets in postmenopausal women: a multicenter, double-blind, randomized, placebo-controlled study. Menopause 2000, 7:236-242.

49. Chan RY, Chen WF, Dong A, Guo D, Wong MS: Estrogen-like activity of ginsenoside Rg1 derived from Panax notoginseng. J Clin Endocrinol Metab 2002, 87:3691-3695.

50. Cho J, Park W, Lee S, Ahn W, Lee Y: Ginsenoside-Rb1 from Panax ginseng C.A. Meyer activates estrogen receptor-alpha and -beta, independent of ligand binding. J Clin Endocrinol Metab 2004, 89:3510-3515.

51. Wiklund IK, Mattsson LA, Lindgren R, Limoni C: Effects of a standardized ginseng extract on quality of life and physiological parameters in symptomatic postmenopausal women: a double-blind, placebocontrolled trial. Swedish Alternative Medicine Group. Int J Clin Pharmacol Res 1999, 19:89-99.

52. Cui $Y$, Shu XO, Gao YT, Cai H, Tao MH, Zheng W: Association of ginseng use with survival and quality of life among breast cancer patients. Am J Epidemiol 2006, 163:645-653.

53. Coon JT, Ernst E: Panax ginseng: a systematic review of adverse effects and drug interactions. Drug Saf 2002, 25:323-344.

54. Greenspan EM: Ginseng and vaginal bleeding. Jama 1983, 249:2018.

55. Punnonen R, Lukola A: Oestrogen-like effect of ginseng. Br Med J 1980, 281:1110.

56. Axelson M, Sjovall J, Gustafsson BE, Setchell KD: Origin of lignans in mammals and identification of a precursor from plants. Nature 1982, 298:659-660.

57. Johnston P: Flaxseed oil and cancer: a-linolenic acid and carcinogenesis. Flaxseed in Human Nutrition Champaign, IL: AOCS Press, Champaign; 1995.

58. Borriello SP, Setchell KD, Axelson M, Lawson AM: Production and metabolism of lignans by the human faecal flora. J App/ Bacteriol 1985, 58:37-43.

59. Kim JY, Park HD, Park E, Chon JW, Park YK: Growth-inhibitory and proapoptotic effects of alpha-linolenic acid on estrogen-positive breast cancer cells. Ann N Y Acad Sci 2009, 1171:190-195.

60. Serraino M, Thompson LU: The effect of flaxseed supplementation on the initiation and promotional stages of mammary tumorigenesis. Nutr Cancer 1992, 17:153-159.

61. Thompson LU, Rickard SE, Orcheson LJ, Seidl MM: Flaxseed and its lignan and oil components reduce mammary tumor growth at a late stage of carcinogenesis. Carcinogenesis 1996, 17:1373-1376.

62. Stoll AL, Locke CA, Marangell LB, Severus WE: Omega-3 fatty acids and bipolar disorder: a review. Prostaglandins Leukot Essent Fatty Acids 1999, 60:329-337.

63. Spence JD, Thornton T, Muir AD, Westcott ND: The effect of flax seed cultivars with differing content of alpha-linolenic acid and lignans on responses to mental stress. J Am Coll Nutr 2003, 22:494-501.

64. Tice JA, Ettinger B, Ensrud K, Wallace R, Blackwell T, Cummings SR: Phytoestrogen supplements for the treatment of hot flashes: the Isoflavone Clover Extract (ICE) Study: a randomized controlled trial. Jama 2003, 290:207-214

65. Saloniemi H, Wahala K, Nykanen-Kurki P, Kallela K, Saastamoinen I: Phytoestrogen content and estrogenic effect of legume fodder. Proc Soc Exp Biol Med 1995, 208:13-17.

66. Boue SM, Wiese TE, Nehls S, Burow ME, Elliott S, Carter-Wientjes $\mathrm{CH}_{\text {, }}$ Shih BY, McLachlan JA, Cleveland TE: Evaluation of the estrogenic effects of legume extracts containing phytoestrogens. J Agric Food Chem 2003, 51:2193-2199.

67. Hwang J, Hodis HN, Sevanian A: Soy and alfalfa phytoestrogen extracts become potent low-density lipoprotein antioxidants in the presence of acerola cherry extract. J Agric Food Chem 2001, 49:308-314.

68. Dixit VP, Joshi SC: Antiatherosclerotic effects of alfalfa meal ingestion in chicks: a biochemical evaluation. Indian J Physiol Pharmacol 1985, 29:47-50.

69. De Leo V, Lanzetta D, Cazzavacca R, Morgante G: Treatment of neurovegetative menopausal symptoms with a phytotherapeutic agent. Minerva Ginecol 1998, 50:207-211.

70. Labrie F: DHEA, important source of sex steroids in men and even more in women. Prog Brain Res 2010, 182:97-148.

71. Barton DL, Loprinzi C, Atherton PJ, Kottschade L, Collins M, Carpenter P, Adjei A, Rummans TA, Shanafelt T, Christensen B, Sloan J:
Dehydroepiandrosterone for the treatment of hot flashes: a pilot study. Support Cancer Ther 2006, 3:91-97.

\section{Pre-publication history}

The pre-publication history for this paper can be accessed here: http://www.biomedcentral.com/1472-6882/11/109/prepub

\section{doi:10.1186/1472-6882-11-109}

Cite this article as: Ma et al.: Estrogenic botanical supplements, healthrelated quality of life, fatigue, and hormone-related symptoms in breast cancer survivors: a HEAL study report. BMC Complementary and Alternative Medicine 2011 11:109.

\section{Submit your next manuscript to BioMed Central and take full advantage of:}

- Convenient online submission

- Thorough peer review

- No space constraints or color figure charges

- Immediate publication on acceptance

- Inclusion in PubMed, CAS, Scopus and Google Scholar

- Research which is freely available for redistribution 